\title{
Upaya Peningkatan Status Gizi Ibu Hamil di Masa Pandemi Covid-19 melalui Program Penyuluhan Rawat Jalan (PENYU RAJA) di Puskesmas Mojosari Kecamatan Mojosari Kabupaten Mojokerto
}

\author{
Dyah Siwi Hety $^{1 *}$, Ika Yuni Susanti ${ }^{2}$, Dhonna Anggreni ${ }^{3}$ \\ ${ }_{1,2}$ Prodi D3 Kebidanan, Sekolah Tinggi Ilmu Kesehatan Majapahit \\ ${ }^{3}$ Prodi S2 Kesehatan Masyarakat, Sekolah Tinggi Ilmu Kesehatan Majapahit \\ *Correspondent Author: dyahsiwi11@gmail.com
}

\begin{abstract}
ABSTRAK
Kehamilan merupakan masa kritis di mana gizi ibu yang baik adalah faktor penting yang mempengaruhi kesehatan ibu dan anak. Masa kehamilan merupakan salah satu masa kritis tumbuh-kembang manusia yang singkat (window of opportunity). Kekurangan gizi yang terjadi di masa tersebut akan menimbulkan kerusakan awal pada kesehatan, perkembangan otak, kecerdasan, kemampuan sekolah, dan daya produksi yang bersifat menetap, tidak dapat diperbaiki. Salah satu upaya yang diharapkan dapat mendukung upaya peningkatan gizi pada ibu hamil, adalah dengan melaksanakan penyuluhan kesehatan tentang gizi ibu hamil melalui Antenatal Care (ANC) Terpadu. Pelayanan ANC Terpadu di batasi hanya hari selasa saja, tidak seperti sebelum ada pandemic covid-19 setiap hari selasa dan rabu. Hal ini untuk antisipasi penyebaran virus covid-19 di Puskesmas Mojosari.Tujuan Pengabmas ini adalah adanya peningkatan pemahaman, sikap serta perilaku ibu hamil tentang pentingnya kebutuhan gizi ibu hamil di masa pandemic Covid-19.

Pertemuan penyuluhan rawat jalan ini dilakukan 4-5 kali pertemuan pada ibu hamil yaitu pemberian materi tentang Gizi Ibu Hamil di masa pandemi Covid-19. Setelah pemberian materi di lanjutkan evaluasi. Evaluasi dilakukan sebanyak kurang lebih 2-3 kali untuk melihat kesesuaian dengan hasil kesepakatan fasilitator dengan peserta. Waktu pertemuan disesuaikan dengan jadwal ANC terpadu di Puskesmas Mojosari, yaitu setiap hari selasa.

Keberhasilan dari program ini di harapkan ibu hamil secara bersama-sama terus berkesinambungan serta selalu berdiskusi, tukar pendapat, tukar pengalaman akan pemenuhan pelayanan kesehatan ibu hamil khususnya tentang pentingnya kebutuhan gizi ibu hamil di masa pandemi Covid-19 yang telah dibimbing oleh fasilitator.
\end{abstract}

Kata Kunci: Peningkatan, Gizi Ibu Hamil, Pandemic Covid-19

Received: July 8, 2021

Revised: August 10, 2021

Accepted: September 1, 2021

\section{(1) (2)}

This is an open-acces article distributed under the terms of the Creative Commons Attribution-ShareAlike 4.0 International License.

\section{PENDAHULUAN}

Kehamilan merupakan masa kritis di mana gizi ibu yang baik adalah faktor penting yang mempengaruhi kesehatan ibu dan anak. Ibu hamil bukan hanya harus dapat memenuhi kebutuhan zat gizi untuk dirinya sendiri, melainkan juga untuk janin yang dikandung. Risiko 


\section{Journal of Community Engagement in Health}

http://jceh.org

https://doi.org/10.30994/jceh.v4i2.247

ISSN: 2620-3758 (print); 2620-3766 (online)

Vol. 4 No 2. Sep 2021. Page. 344-347

komplikasi selama kehamilan atau kelahiran paling rendah bila pertambahan berat badan sebelum melahirkan memadai.

Masa kehamilan merupakan salah satu masa kritis tumbuh-kembang manusia yang singkat (window of opportunity). perkembangannya. Khusus untuk ibu hamil, jika janin dalam kandungannya mengalami kekurangan gizi, maka anaknya kelak pada usia dewasa akan berisiko lebih tinggi untuk menderita penyakit degeneratif (diabetes, hipertensi, penyakit jantung, stroke) dibandingkan dengan yang tidak mengalami kekurangan gizi.

Untuk mendukung upaya-upaya Pemerintah dalam penurunan AKI, telah dilaksanakan beberapa kegiatan pelayanan kesehatan ibu, baik di tingkat masyarakat, Puskesmas dan Rumah Sakit, dengan melibatkan lintas program dan lintas sektor terkait serta jejaring lain yang turut mendukung upaya tersebut. Salah satu upaya yang diharapkan dapat mendukung upaya tersebut, adalah dengan melaksanakan penyuluhan kesehatan tentang gizi ibu hamil melalui Antenatal Care (ANC) Terpadu berkualitas yang merupakan penyempurnaan pelayanan ANC dengan menggunakan berbagai sumber daya yang tersedia di fasilitas pelayanan kesehatan dasar. Dengan pelayanan ANC terpadu tersebut, didorong agar pelayanan ANC lebih terpadu dan berkualitas dengan melengkapi beberapa pemeriksaan kehamilan oleh dokter umum, pemeriksaan gigi, ahli gizi, pemeriksaan laboratorium, konseling serta pemberian asam folat. Pelayanan antenatal terpadu merupakan pelayanan antenatal komprehensif dan berkualitas yang diberikan kepada semua ibu hamil secara terpadu dengan program lain yang memerlukan intervensi lanjutan selama kehamilannya. Tujuan ANC terpadu adalah untuk memenuhi hak setiap ibu hamil memperoleh pelayanan antenatal yang berkualitas, sehingga mampu menjalani kehamilan dengan sehat, bersalin dengan selamat, dan melahirkan bayi yang sehat.

Kehamilan merupakan suatu proses faali yang menjadi awal kehidupan generasi penerus. Salah satu kebutuhan esensial untuk proses reproduksi sehat adalah terpenuhinya kebutuhan energi, protein, karbohidrat, vitamin, dan mineral serta serat. Kurangnya asupan zat gizi makro (karbohidrat, protein, dan lemak) maupun zat gizi mikro (asam folat, zat besi, seng, kalsium, iodium, dan lain-lain) dapat menimbulkan masalah gizi dan kesehatan pada ibu dan bayinya.

Penerapan ANC Terpadu dilaksanakan sesuai protokol kesehatan di masa pandemic Covid-19 ini. Penerapannya dengan melaksanakan 3M, antara lain: mencuci tangan pakai sabun dengan air yang mengalir, memakai masker serta menjaga jarak aman minimal sekitar 1 meter. Jika dalam kondisi tertentu, semisal tidak ada air dan sabun untuk membersihkan tangan, solusi lainnya adalah memakai cairan yang berbasis setidaknya 60\% alcohol seperti hand sanitizer. Penerapan $3 \mathrm{M}$ di Puskesmas Mojosari ini sudah tersedia dan di jalankan sesuai protocol kesehatan. Penerapan $3 \mathrm{M}$ ini yang paling utama adalah menjaga jarak atau social distancing dengan jarak minimal 1 meter, termasuk dengan menghindari kerumunan. Jumlah yang berkunjung di pelayanan poli KIA Puskesmas Mojosari juga di batasi jumlahnya.

Pelayanan ANC Terpadu di batasi hanya hari selasa saja, tidak seperti sebelum ada pandemic covid-19 setiap hari selasa dan rabu. Hal ini untuk antisipasi penyebaran virus covid19 di Puskesmas Mojosari. Adapun wilayah Puskesmas Mojosari terdiri dari 9 wilayah, yaitu: Desa Awang-awang, desa Belahan Tengah, desa Sumbertanggul, desa Randubangu, desa Seduri, kelurahan Kauman, kelurahan Sarirejo, kelurahan Sawahan dan kelurahan Mojosari. Sebagai mitra kami nanti adalah ibu hamil yang melakukan pemeriksaaan kehamilan di Puskesmas Mojosari. Kegiatan pendidikan dan pelatihan pada ibu hamil ini bertujuan untuk memberikan pengalaman dan pengetahuan kepada ibu hamil tentang apa itu Program ANC Terpadu di era new normal ini. Mulai dari pengertian, tujuan, manfaat dan jadwal kunjungannya. Kegiatan tersebut juga untuk meningkatkan cakupan kunjungan ibu hamil dan 


\section{Journal of Community Engagement in Health}

http://jceh.org

https://doi.org/10.30994/jceh.v4i2.247

ISSN: 2620-3758 (print); 2620-3766 (online)

Vol. 4 No 2. Sep 2021. Page. 344-347

interaksi antar ibu hamil agar mereka dapat bertukar pikiran dan pengalaman seputar peningkatan status kesehatan pada era new normal ini.

\section{BAHAN DAN METODE}

1. Survei Lapangan.

Survei lapangan bertujuan untuk mengamati situasi dan keadaan wilayah Puskesmas, yang direncanakan sebagai objek sasaran.

2. Menentukan Sasaran

Sasaran program penyuluhan adalah ibu hamil diyang berada di Wilayah kerja Puskesmas Mojosari Kecamatan Mojosari Kabupaten Mojokerto.

\section{Koordinasi}

Berkoordinasi dengan pihak Puskesmas Mojosari, yaitu khususnya bagian KIA dan karyawan yang lainnya untuk persamaan persepsi serta menentukan kesepakatan antara pelaksana program dengan masyarakat.

4. Sosialisasi Program

Sosialisasi program bertujuan untuk memberikan informasi mengenai rencana serangkaian pelaksanaan program yang disampaikan kepada bidan dan karyawan Puskesmas yang berhubungan langsung dengan program ini.

\section{Pelaksanaan Program}

Pertemuan penyuluhan rawat jalan ini dilakukan 4-5 kali pertemuan pada ibu hamil yaitu dengan pemberian materi tentang Gizi Ibu Hamil di masa pandemi Covid-19 ini. Setelah pemberian materi di lanjutkan evaluasi. Evaluasi dilakukan sebanyak kurang lebih 2-3 kali untuk melihat kesesuaian dengan hasil kesepakatan fasilitator dengan peserta. Pada setiap pertemuan, materi yang akan disampaikan adalah tentang Kebutuhan gizi ibu hamil. Pada setiap akhir pertemuan dilakukan tanya jawab tentang materi yang telah diberikan. Pada kegiatan program penyuluhan ini merupakan pemberian materi bagi ibu hamil, setelah sampai di rumah diharapkan dapat dipelajari, dipahami tentang pentingnya pemenuhan kebutuhan gizi pada ibu selama kehamilan di masa pandemi Covid-19. Waktu pertemuan disesuaikan dengan jadwal ANC terpadu di Puskesmas Mojosari, yaitu setiap hari selasa.

\section{HASIL}

Pelaksanaan kegiatan ini dimulai dengan melakukan persiapan penyusunan proposal kemudian menyusun materi dan berkoordinasi dengan bidan penanggung jawab/koordinator untuk menyesuaikan dengan kegiatan ibu hamil. Jumlah peserta dalam kegiatan ini di batasi sekitar 30 ibu hamil. Jumlah ini lebih sedikit di banding pada saat sebelum ada pandemi. Covid19.

Kegiatan ini secara garis besar menunjukkan hal yang menggembirakan yaitu hampir 100 $\%$ peserta merespon positif dalam pemahaman tentang Kebutuhan Gizi Ibu Hamil di masa pandemic Covid-19.

\section{PEMBAHASAN}

Para Mitra sebagian adalah ibu-ibu yang bekerja baik di pemerintah, wiraswasta dan sebagian besar adalah pekerja pabrik. Baik di perusahaan atau pabrik-pabrik serta home industry. Dampak dari keadaan tersebut adalah jarang ibu-ibu yang periksa di puskesmas, apalagi pada era new normal ini. Mereka takut berkunjung ke fasilitas pelayanan kesehatan dan lebih memilih ke dokter praktek swasta ataupun ke Bidan Praktek Mandiri (BPM). Ibu hamil sebagai bagian dari anggota masyarakat dalam kegiatan kesehatan merupakan individu yang terdampak langsung dan paling rentan pada masa pandemic Covid-19 saat ini, sehingga 


\section{Journal of Community Engagement in Health}

http://jceh.org

https://doi.org/10.30994/jceh.v4i2.247

ISSN: 2620-3758 (print); 2620-3766 (online)

Vol. 4 No 2. Sep 2021. Page. 344-347

pengetahuannya perlu di tingkatkan, terutama tentang perawatan kesehatan pada ibu hamil, ibu bersalin, ibu nifas, neounatus, bayi, balita dan KB pada masa pandemi Covid-19 yang saat ini masih berlangsung. Evaluasi kegiatan tersebut:

1. Kegiatan berjalan dengan lancar, peserta mengikuti kegiatan dengan tertib dan mematuhi protokol kesehatan,

2. Dari kegiatan tersebut peserta dapat mengetahui tentang manfaat gizi pada ibu hamil.

\section{REFERENSI}

Anggrita, S., Mardiatul, U. I., \& Ramalida, D. (2015). Asuhan Kebidanan Pada Kehamilan. Bogor: IN Media.

https://duniabidan.com/kehamilan-kandungan/standar-10t-pemeriksaan-kehamilanantenatal-anc.html

Infocovid 19.jatimprov.go.id

KepMenkes RI No. HK .01.07/Menkes/328/2020

Kementrian Kesehatan RI. (2015). Bahan Ajar Kesehatan Ibu dan Anak. Jakarta Selatan : Pusat Pendidikan Sumber Daya Manusia Kesehatan.

Kementrian Kesehatan RI. (2017). Bahan Ajar Gizi dalam Daur Kehidupan. Jakarta : Pusat Pendidikan Sumber Daya Manusia Kesehatan.

Kementrian Kesehatan RI. (2017). Penilaian Status Gizi. Jakarta : Pusat Pendidikan Sumber Daya Manusia Kesehatan.

Rukiah, A. Y., Yulianti, L., Maemunah, \& Susilawati, L. (2013). Asuhan Kebidanan Kehamilan. Jakarta: CV. Trans Info Media. 